\title{
Hygroscopicity and Ultraviolet (UV) Deterioration Characteristics of Finished Woods ${ }^{1}$
}

\author{
Ji-Yeol KIM ${ }^{2} \cdot$ Byung-Ro KIM(D) ${ }^{2, \dagger}$
}

\begin{abstract}
This study investigated the hygroscopicity and UV deterioration characteristics of 3 domestic and 4 imported woods using natural oil, stain, and varnish paints. In terms of hygroscopicity, it was found that the hygroscopicity of the painted wood was lower than that of the unpainted wood, and that as the number of coatings increased, the hygroscopicity decreased. In terms of anti-absorption, oil-based chemical paints showed higher resistance than water-based paints, and natural oils showed results comparable to oil-based paints. As for the UV deterioration, the amount of color change of the painted wood was lower than that of the unpainted wood, and there was no significant difference according to the number of times of painting. The amount of color change was found to be low in oil-based paints and hardwoods. Through this study, we confirmed effective moisture blocking and small color changes during painting using paints, and it is believed that wood can be protected from internal and external defects through selective and efficient painting based on data for excellent painting performance.
\end{abstract}

Keywords: hygroscopicity, UV deterioration, coating material, natural oil, stain, varnish, finished wood

\section{INTRODUCTION}

Wood is a material that has a close relationship with mankind due to its easy accessibility, processability and usability with the beginning of mankind. In addition, it has various performances such as high specific strength and elasticity, beautiful pattern and color, texture, fragrance, and humidity control, so it has been recognized as an important material indispensable to us humans. Even today, it is widely used as a material for architecture, civil engineering, furniture, musical instruments, ships, and packaging (Kim, 2006). Wood, a biological material, differs from inorganic materials such as iron and plastic in that its physical properties change according to changes in humidity. If the wood is placed in a place with high relative humidity (RH), it absorbs moisture from the outside air. Conversely, if the wood is placed in a place with low relative humidity, moisture in the wood is dehumidified. That is, moisture absorption or dehumidification continues until an equilibrium state is reached by the difference between the atmospheric water vapor pressure and the moisture attraction in the wood, which is called the hygroscopicity of wood (Kang et al., 2008). The hygroscopicity of wood is the reason why it is evaluated as a human-friendly material by controlling the humid-

\footnotetext{
${ }^{1}$ Date Received July 8, 2021, Date Accepted August 5, 2021

2 Department of Wood and Paper Science, Chungbuk National University, Cheongju 28644, Republic of Korea

$\dagger$ Corresponding author: Byung-Ro KIM (e-mail: brkim@cbnu.ac.kr, ORCID: 0000-0001-5800-2058)
} 
ity of the human living environment, but it is a factor that causes defects by causing changes in physical properties, dimensional changes, and cracking. Among them, dimensional change is the main cause of quality problems that occur in the process of manufacturing and using wood products. Therefore, it is said that understanding the relationship between wood and moisture is important for the stable use of wood products used for various purposes such as building materials and furniture (Hoadley, 1980; Kang et al., 2008).

Just as humans use cosmetics to protect their skin, wood is also painted using paints to suppress various defect factors in addition to defects caused by moisture. In order to manufacture wooden products such as furniture or musical instruments, it is finally subjected to a painting process by lumbering, drying, bonding, and assembling. In particular, the painting process is the final finishing process for the purpose of beautifying the aesthetics of the product and protecting it from changes in the surrounding environment. By painting, wood can be protected from contamination, aging and damage of the material, and it can improve moisture resistance, water resistance, flame resistance, oil resistance, chemical resistance, insect repellency, antibacterial and abrasion resistance, etc. defects can be prevented (Jeong, 1994; DAPA, 2008; $\mathrm{Na}$ et al., 2015; Oh and Park, 2015; Hwang et al., 2018; Kim, 2018; Park et al., 2018; Arsyad et al., 2019; Park et al., 2020; Park et al., 2021). However, there are many influencing factors compared to painting of other materials, such as the complex structure and properties of wood, differences in various species and characteristics, and shrinkage and expansion due to the effects of temperature and humidity. There are difficulties such as understanding it sufficiently (Chung and Kim, 2001).

A study on the relationship between wood and moisture is essential and can be said to be a basic field of wood use, and studies related to hygroscopicity are as follows. A study on the moisture absorption and de- sorption properties of douglas fir, hinoki, larch, plywood, and WML board ${ }^{R}$ in response to humidity variation (Park and Jo, 2020), and water absorption and dimensional stability of heat-treated fast-growing hardwoods (Priadi et al., 2019), and hygroscopic property of heat treated yellow poplar wood (Chang at el., 2019), and evaluation of material properties of acetylated medium density fiberboard (Lee and Kim, 2020) were recently studied. As such, recent studies on hygroscopicity have been conducted through several studies, but research on the hygroscopicity of wood finished with paint is insufficient. Therefore, the purpose of this study is to scientifically reveal the effect of blocking moisture and improving properties by coating using paints, and also to make efficient painting by examining the characteristics according to species and paints. For this purpose, the hygroscopicity and UV deterioration characteristics by coating treatment for each major paint were investigated for domestic and imported materials that are currently mainly used.

\section{MATERIALS and METHODS}

\subsection{Materials}

\subsubsection{Wood}

A total of 7 species was selected for this study, including 2 softwood species and 5 hardwood species. For Korean red pine (Pinus densiflora), Japanese larch (Larix kaempferi), and zelkova (Zelkova serrata), domestic woods were used, and for walnut (Juglans regia), white oak (Quercus alba) and red oak (Quercus rubra) from North America, and merbau (Intsia bijuga) from Southeast Asia, imported woods obtained from domestic company Y were used. The domestic woods were naturally dried at the natural drying plant of Chungbuk National University, and the imported woods was imported from North America and Southeast Asia to Korea and subjected to natural dry- 
Table 1. Types, composition, and specific gravity of paints

\begin{tabular}{c|l|c}
\hline Classification & \multicolumn{1}{|c}{ Composition } & Specific gravity \\
\hline \hline Natural oil & Citrus oil, Linseed oil, Linseed stand oil, Dammar, Beeswax, Glycerin ester, etc. & 0.88 \\
\hline Water based stain & $\begin{array}{l}\text { Acrylic emulsion resin, Non-toxic organic antibacterial agent with antibacterial } \\
\text { properties, etc. }\end{array}$ & 1.03 \\
\hline Oil based stain & Linseed oil, Special pigments, Antiseptics, etc. & 0.95 \\
\hline Water based varnish & Acrylic / urethane resin, Quick-drying aqueous copolymer special resin, etc. & 1.0 \\
\hline Oil based varnish & Oily polyurethane, etc. & 0.9 \\
\hline
\end{tabular}

ing for about $2 \sim 3$ years. In addition, both domestic and imported materials were obtained from lumber, and the specimens were made from solid wood boards with a size of $50(\mathrm{~L}) \times 50(\mathrm{R}) \times 10(\mathrm{~T}) \mathrm{mm}$ by removing defects such as knots and cracks in the wood.

\subsubsection{Paints and finishing}

Among the paints for wood distributed in the domestic market, a total of 5 paints was selected: natural oil from German company A, which is mainly used for furniture, water-based and oil-based stains from domestic S, and water-based and oil-based varnish from domestic $\mathrm{N}$ company. Table 1 shows the types, components, and specific gravity of the paints for this study. The application amount was determined as 100 $\mathrm{g} / \mathrm{m}^{2}$ by calculating an appropriate amount for a specimen area of $50(\mathrm{~L}) \times 50(\mathrm{R}) \times 10(\mathrm{~T}) \mathrm{mm}$. Also, in order to find out the difference according to the number of times of painting, wood that was painted 1, 2, and 3 times, respectively, was produced. For the painting, all surfaces were uniformly painted by using a sponge brush, and after checking the dry state of the coating film, it was repainted.

\subsection{Method}

\subsubsection{Hygroscopcity}

According to the Korean industrial standard KS F 2205 (test method for hygroscopicity of wood), it was measured at $40^{\circ} \mathrm{C}$ under $75 \% \mathrm{RH}$ and $90 \%$ temperature and humidity conditions. A thermo-hygrostat
(LAB TECH, LHT-2250O) capable of controlling temperature and humidity was used, and the measurement area was the front. After measuring at $40^{\circ} \mathrm{C}$ under the condition of $\mathrm{RH} 75 \%$, the measurement was changed to the condition of RH $90 \%$. Hygroscopicity was expressed as the equilibrium moisture content (Equation. 1), and the anti-absorption (AA) of the coating material was calculated using the equilibrium moisture content (Equation. 2).

$$
\begin{gathered}
40^{\circ} \mathrm{C} \text { RH } 75 \% \text { EMC }(\%)= \\
\left(\mathrm{W}_{\mathrm{ch}}-\mathrm{W}\right) / \mathrm{W} \times 100 \\
40^{\circ} \mathrm{C} \text { RH } 90 \% \mathrm{EMC}(\%)= \\
\left(\mathrm{W}_{\infty}-\mathrm{W}\right) / \mathrm{W} \times 100
\end{gathered}
$$

where, $\mathrm{W}_{\text {oh }}$ : equilibrium weight of $40^{\circ} \mathrm{C} \mathrm{RH} 75 \%(\mathrm{~g})$

$\mathrm{W}$ : oven dry weight $(\mathrm{g})$

$\mathrm{W}_{\infty}$ : equilibrium weight of $40^{\circ} \mathrm{C} \mathrm{RH} 90 \%(\mathrm{~g})$

$$
\text { AA }(\%)=\left(W_{u t}-W_{t}\right) / W_{u t} \times 100
$$

where, $\mathrm{W}_{\mathrm{ut}}$ : weight of untreated $(\mathrm{g})$

$\mathrm{W}_{\mathrm{t}}$ : weight of treated $(\mathrm{g})$

\subsubsection{UV deterioration}

UV deterioration was performed using an accelerated deterioration tester (QUV/SE) at UV $60^{\circ} \mathrm{C}$. for 312 hours (UVA-340 lamp, radiation amount 0.77 $\mathrm{W} / \mathrm{m}^{2} / \mathrm{nm}$ ). In addition, the specimen was placed facing the lamp so that it could receive UV directly, and 
the distance from the lamp was arranged at $50 \mathrm{~mm}$. The optical properties of the samples before and after UV deterioration were measured using a colorimeter (X-RITE, COLOR EYE-7000A) to measure $\mathrm{L}^{*}, \mathrm{a}^{*}$, and $\mathrm{b}^{*}$ values according to the CIE $\mathrm{L}^{*} \mathrm{a}^{*} \mathrm{~b}^{*}$ color space. Four points were measured to obtain an average value. For the color difference $(\Delta \mathrm{E})$, the following equation (Equation 3) was used, and the degree of color change according to the $\Delta \mathrm{E}$ value is shown in Table 2. In addition, the Anti Color Changes (ACC) of the painted material was calculated using the amount of color change (Equation 4).

Table 2. Judgement standard for color difference

\begin{tabular}{cc}
\hline \multicolumn{1}{c}{$\mathrm{E}$} & Degree of sensory perception \\
\hline \hline $0.0 \sim 0.5$ & Trace \\
\hline $0.5 \sim 1.5$ & Slight \\
\hline $1.5 \sim 3.0$ & Noticeable \\
\hline $3.0 \sim 6.0$ & Appreciable \\
\hline $6.0 \sim 12.0$ & Much \\
\hline 12.0 over & Very much \\
\hline
\end{tabular}

$$
\triangle \mathrm{E}=\left[\left(\triangle L^{*}\right)^{2}+\left(\triangle a^{*}\right)^{2}+\left(\triangle b^{*}\right)^{2}\right]^{1 / 2}
$$

where, $\triangle E$ : total color difference

$\triangle L^{*}$ : difference in $\mathrm{L}^{*}$ (lightness)

$\triangle a^{*}:$ difference in $\mathrm{a}^{*}$ (redness and greenness)

$\triangle b^{*}$ : difference in $\mathrm{b}^{*}$ (yellowness and blueness)

$$
\operatorname{ACC}(\%)=\left(C_{u t}-C_{t}\right) / C_{u t} \times 100
$$

where, $\mathrm{C}_{\mathrm{ut}}$ : color changes of untreated $(\mathrm{g})$

$\mathrm{C}_{\mathrm{t}}$ : color changes of treated $(\mathrm{g})$

\subsubsection{Statistical analysis}

In this study, statistical analysis was performed with Duncan test $(p<0.05)$ using IBM SPSS Statistics 24 program to test for statistical significance according to the number of coats.

\section{RESULTS and DISCUSSION}

\subsection{Hygroscopicity}

Table 3 shows the average equilibrium moisture

\begin{tabular}{|c|c|c|c|c|c|c|c|c|c|c|c|c|c|c|c|c|c|}
\hline \multirow{2}{*}{$\begin{array}{l}\text { Coating } \\
\text { material }\end{array}$} & \multirow{2}{*}{ ondition } & \multicolumn{2}{|c|}{ Korean red pine } & \multirow{2}{*}{$\begin{array}{c}\text { Japanese } \\
\text { EMC }\end{array}$} & \multirow{2}{*}{$\begin{array}{l}\text { larch } \\
\text { AA }\end{array}$} & \multicolumn{2}{|c|}{ Zelkova } & \multicolumn{2}{|c|}{ Walnut } & \multicolumn{2}{|c|}{ Merbau } & \multirow{2}{*}{$\begin{array}{l}\text { White } \\
\text { EMC }\end{array}$} & \multirow{2}{*}{$\frac{\text { oak }}{\text { AA }}$} & \multirow{2}{*}{$\begin{array}{r}\text { Red } \\
\text { EMC }\end{array}$} & \multirow{2}{*}{$\frac{\text { oak }}{\text { AA }}$} & \multicolumn{2}{|c|}{ Average } \\
\hline & & EMC & AA & & & EMC & AA & EMC & AA & EMC & AA & & & & & EMC & $\mathrm{AA}$ \\
\hline \multirow{2}{*}{ Intreated } & 50 & 11.0 & & 110 & & 9.8 & & 10.3 & & 10.6 & & 10.8 & & 10.5 & & 10.2 & \\
\hline & & & & & & 14.9 & & 15.4 & & 13.9 & & 14.8 & & 14.9 & & 14.6 & \\
\hline \multirow{2}{*}{ Natural oi } & $40^{\circ} \mathrm{C} 750$ & 100 & & 10.6 & & 9.3 & & 9.9 & & 10.0 & 5.2 & 10.3 & & 10.3 & 1.9 & 10.2 & 3.9 \\
\hline & $40^{\circ} \mathrm{C} 90 \%$ & 1 & & & & 13.7 & 7.6 & 14.9 & 3.3 & 13.2 & 5.0 & 14.0 & 5.0 & 14.3 & 4.0 & 14.6 & 3.9 \\
\hline \multirow{2}{*}{$\begin{array}{l}\text { Water based } \\
\text { stain }\end{array}$} & $40^{\circ} \mathrm{C} 75 \%$ & & & & & 9.4 & 4.8 & 10.1 & 2.6 & 10.4 & 2.3 & 10.6 & 1.8 & 10.4 & 1.3 & 10.3 & 2.4 \\
\hline & $40^{\circ} \mathrm{C} 90 \%$ & $160+2)$ & & & 0.7 & 14.0 & 5.6 & 15.2 & 1.5 & 13.6 & 1.9 & 14.6 & 0.9 & 14.5 & 2.3 & 14.9 & 2.0 \\
\hline \multirow{2}{*}{ Oil based stain } & $40^{\circ} \mathrm{C} 75 \%$ & 10.7 & 2.8 & & 0.4 & 9.6 & 2.5 & 9.9 & 4.0 & 10.1 & 5.0 & 10.6 & 2.3 & 10.2 & 2.7 & 10.3 & 2.8 \\
\hline & $40^{\circ} \mathrm{C} 90 \%$ & 15.4 & 4.3 & 16.0 & 2.0 & 14.2 & 4.5 & 14.9 & 3.3 & 13.2 & 4.5 & 14.4 & 2.6 & 14.0 & 6.0 & 14.6 & 3.9 \\
\hline \multirow{2}{*}{$\begin{array}{l}\text { Water based } \\
\text { varnish }\end{array}$} & $40^{\circ} \mathrm{C} 75 \%$ & 10.9 & & & & 9.2 & 6.8 & 10.0 & 2.9 & 10.4 & 2.2 & 10.4 & 4.0 & 10.2 & 2.7 & 10.3 & 3.1 \\
\hline & $40^{\circ} \mathrm{C} 90 \%$ & & & & & 13.9 & 6.3 & 14.9 & 3.0 & 13.6 & 1.6 & 14.4 & 2.4 & 14.3 & 4.0 & 14.7 & 3.2 \\
\hline \multirow{2}{*}{$\begin{array}{l}\text { Oil based } \\
\text { varnish }\end{array}$} & $40^{\circ} \mathrm{C} 75 \%$ & 10.0 & 3.9 & & 10.0 & 9.1 & 7.3 & 9.4 & 8.7 & 9.5 & 9.9 & 9.7 & 10.4 & 10.2 & 2.8 & 9.8 & 7.6 \\
\hline & $40^{\circ} \mathrm{C} 90 \%$ & 15.4 & 4.5 & 15.1 & 7.3 & 13.6 & 8.3 & 14.5 & 5.9 & 12.6 & 8.7 & 14.0 & 5.4 & 13.7 & 7.5 & 14.1 & 6.8 \\
\hline \multirow[b]{2}{*}{ Average } & $40^{\circ} \mathrm{C} 75 \%$ & 10.8 & 2.0 & 10.6 & 3.9 & 9.3 & 5.4 & 9.9 & 4.6 & 10.1 & 4.9 & 10.3 & 4.7 & 10.3 & 2.3 & 10.2 & 4.0 \\
\hline & $40^{\circ} \mathrm{C} 90 \%$ & 15.7 & 2.6 & 15.8 & 3.0 & 13.9 & 6.4 & 14.9 & 3.4 & 13.2 & 4.4 & 14.3 & 3.3 & 14.1 & 4.7 & 14.6 & 4.0 \\
\hline
\end{tabular}

Table 3. $\mathrm{EMC}^{*}, \mathrm{AA}^{*}$ according to coating material and species under $40^{\circ} \mathrm{C}$ with $\mathrm{RH} 75 \%$ and $90 \%$ Unit: $\%$

EMC $^{*}$ : Equilibrium Moisture Content, $\mathrm{AA}^{*}$ : Anti Absorption 
content and anti-absorption rate of 1,2, and 3 times for each paint and throughout the temperature and humidity conditions of $75 \% \mathrm{RH}$ and $90 \%$ at $40^{\circ} \mathrm{C}$, Fig. 1 shows the equilibrium moisture content and Duncan test results of unpainted wood by species and natural oil-painted woods according to the number of 1,2 , and 3 coats under temperature and humidity conditions of $75 \% \mathrm{RH}$ and $90 \%$ at $40^{\circ} \mathrm{C}$.

The unpainted wood had equilibrium moisture content of $11.0 \%$ and $16.1 \%$ for Korean red pine, $11.0 \%$ and $16.3 \%$ for Japanese larch, $9.8 \%$ and $14.9 \%$ for zelkova, $10.3 \%$ and $15.4 \%$ for walnut, $10.6 \%$ and $13.9 \%$ for merbau, $10.8 \%$ and $14.8 \%$ for white oak, $10.5 \%$ and $14.9 \%$ for red oak under temperature and humidity conditions of $75 \% \mathrm{RH}$ and $90 \%$ at $40^{\circ} \mathrm{C}$, respectively. Kim et al. (2018) found that, in a study on the hygroscopicity of major Korean tree species, the equilibrium moisture content was $10.7 \%$ and $14.6 \%$ for softwood and $10.9 \%$ and $15.4 \%$ for hardwood, respectively, under temperature and humidity conditions of $75 \% \mathrm{RH}$ and $90 \%$ at $40^{\circ} \mathrm{C}$. Haishi et al. (1973) reported that, in a study on the equilibrium moisture content of major Japanese tree species, the equilibrium moisture content was $12.3 \%$ and $16.9 \%$ for softwoods and $12.3 \%$ and $17.4 \%$ for hardwoods, respectively, at $40^{\circ} \mathrm{C}$ under $75 \% \mathrm{RH}$ and $90 \%$ temperature and humidity conditions. The equilibrium moisture content of the unpainted woods in this study (at $40^{\circ} \mathrm{C}$ under the tem-
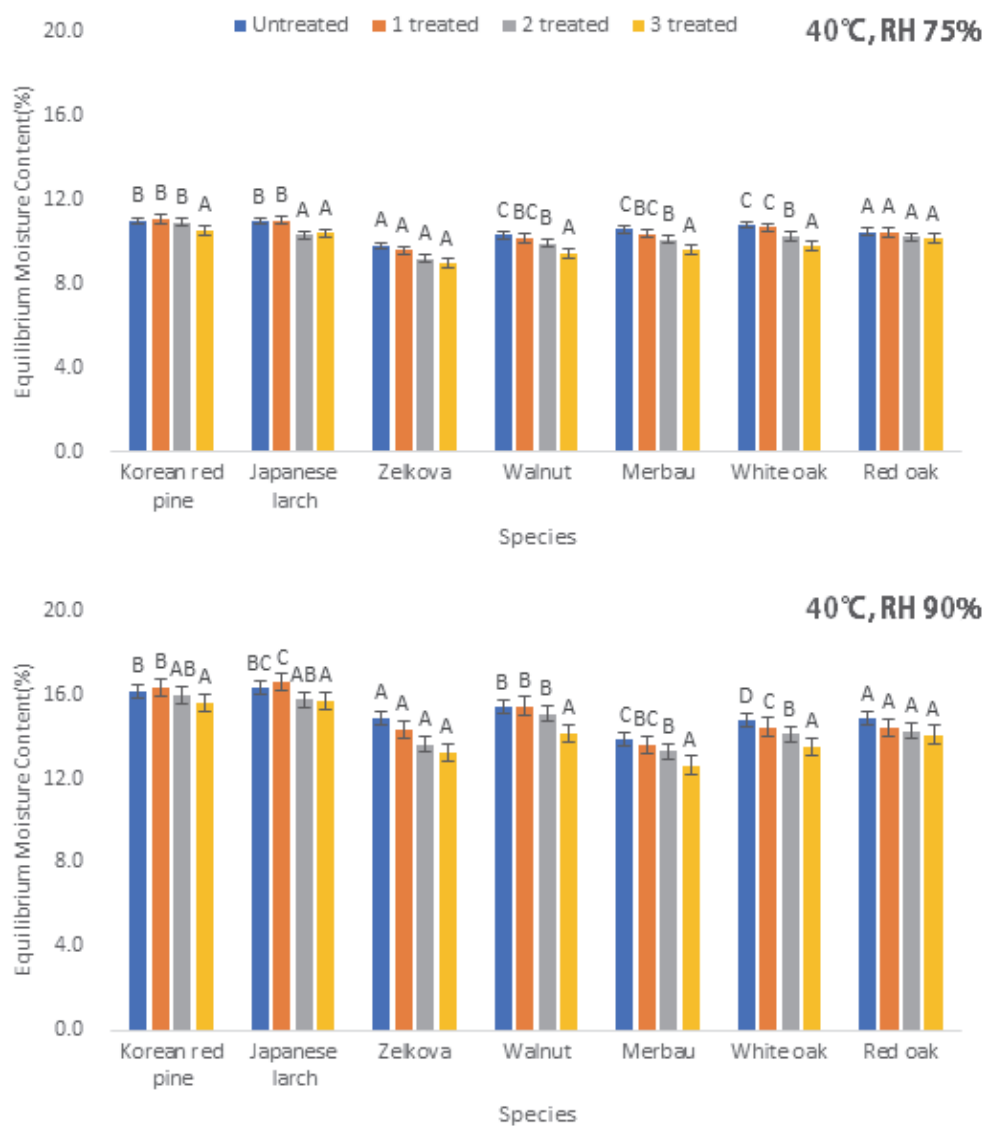

Fig. 1. Equilibrium moisture content of natural oil under $40^{\circ} \mathrm{C}$ with $\mathrm{RH} 75 \%$ and $90 \%$. 
perature and humidity conditions of $75 \% \mathrm{RH}$ and $90 \%$ ) was $11.0 \%$ and $16.2 \%$ for softwood and $10.4 \%$ and $14.7 \%$ for hardwood, respectively. When compared with the study of Kim et al. (2018) under the same temperature and humidity conditions, the softwood and hardwoods of this study showed similar equilibrium moisture content, but softwood and hardwood showed low equilibrium moisture content. for both conditions than the study of Haishi et al. (1973).

The average equilibrium moisture content of the painted wood under temperature and humidity conditions of $75 \% \mathrm{RH}$ and $90 \%$ at $40{ }^{\circ} \mathrm{C}$ was $10.8 \%$ and $15.7 \%$ for Korean red pine, $10.6 \%$ and $15.8 \%$ for Japanese larch, $9.3 \%$ and $13.9 \%$ for zelkova, and $9.9 \%$ and $14.9 \%$ for walnut, $10.1 \%$ and $13.2 \%$ for merbau, $10.3 \%$ and $14.3 \%$ for white oak, $10.3 \%$ and $14.1 \%$ for red Oak. Lee et al. (2002) showed that linseed, castor, olive, soybean, perilla, and sunflower seed oils and fats were applied to pine wood in a study on hygroscopicity through natural oil treatment. It was reported that the oil-painted wood absorbed less moisture than the unpainted wood. In this study, the amount of moisture absorption of the natural oil coating material was found to be less than that of the unpainted wood, and it is judged that the moisture absorption was suppressed through the coating treatment.

The anti-absorption rate by species was $5.4 \%$ for zelkova, $4.9 \%$ for merbau, $4.7 \%$ for white oak, $4.6 \%$ for walnut, 3.9\% for Japanese larch, 2.3\% for red oak, and $2.0 \%$ for Korean red pine, with an average of $4.4 \%$ hardwoods and $3.0 \%$ of softwoods under temperature and humidity conditions of $75 \% \mathrm{RH}$ at $40^{\circ} \mathrm{C}$. Under the temperature and humidity conditions of 4 $0^{\circ} \mathrm{C}$ and $90 \% \mathrm{RH}$, zelkova $6.4 \%$, red oak $4.7 \%$, merbau $4.4 \%$, walnut $3.4 \%$, white oak $3.3 \%$, Japanese larch $3.0 \%$, and Korean red pine $2.6 \%$, as average for hardwood $4.2 \%$ and for softwoods $2.8 \%$. Overall, the results show that hardwoods such as zelkova, merbau, white oak, walnut, and red oak show higher resistance to hygroscopicity than softwoods such as Korean red pine and Japanese larch in temperature and humidity conditions of $75 \% \mathrm{RH}$ and $90 \%$ at $40^{\circ} \mathrm{C}$. In softwoods, tracheid occupy more than $90 \%$ of the cell wall structure, and in hardwoods, vessel elements for $50 \%$, wood fibers for $25 \%$, and ray cells for $20 \%$, indicating a difference in permeability (Lee, 2018). As such, softwoods with a relatively simple structure and hardwoods with differentiated functions show anatomical differences (Kwon et al., 2020). It is judged that the differences according to species in the moisture absorption process after painting are factors such as different permeability and anatomical characteristics between species. As such, it is judged that there is a difference depending on the species in the moisture absorption process after painting due to differences in permeability and anatomical characteristics between different species.

The anti-absorption rate by paints was $7.6 \%$ for oil-based varnish, $3.9 \%$ for natural oil, 3.1\% for water-based varnish, $2.8 \%$ for oil-based stain, and $2.4 \%$ for water-based stain, with an average of $4.8 \%$ oil-based painted and $2.8 \%$ of water-based painted under temperature and humidity conditions of $75 \% \mathrm{RH}$ at $40^{\circ} \mathrm{C}$. Under the temperature and humidity conditions of $40^{\circ} \mathrm{C}$ and $90 \% \mathrm{RH}$, oil-based varnish $6.8 \%$, natural oil and oil-based stain 3.9\%, water-based varnish $3.2 \%$, and water-based stain $2.0 \%$, as average of for oil-based paints $4.9 \%$ and for water-based paints $2.6 \%$. The results of $40^{\circ} \mathrm{C}$, RH $75 \%$ and $\mathrm{RH} 90 \%$ temperature and humidity conditions were generally similar. It was confirmed that oil-based paints such as oil-based varnishes, natural oils, and oil-based stains showed higher anti-absorption than water-based paints such as water-based stains and water-based varnishes. In addition, as the number of coatings increased, the equilibrium moisture content decreased. As a result of Duncan test statistical analysis, there was a more significant difference between the unpainted wood and 
the 3 coats than the 1 and 2 coats. It was confirmed that the most effective moisture absorption inhibitory power was obtained (Fig. 1).

The fact that the painted wood shows lower hygroscopicity than the unpainted wood, and that the hygroscopicity decreases as the number of coatings increases is considered to be influenced by the suppression of moisture absorption of wood by painting with paint (KFRI, 1989). The natural oil in this study showed high anti-hygroscopicity compared to other chemical paints, and low hygroscopicity compared to traditionally used natural oils (Lee et al., 2011). Existing natural paints were mainly used alone by extracting and refining them from fruits, seeds, saps of plants, or bodily fluids and secretions of insects (Kim et al., 2002; DAPA, 2008; Kim, 2010; Lee et al., 2011; Park, 2018). However, unlike the existing natural paints, the natural oil used in this study is a paint manufactured by mixing natural extracts. It has been improved compared to before by adding natural oils and fats such as linseed oil, orange oil, dammar wax, and beeswax, showing excellent moisture barrier properties (Choi, 2013; Lee et al., 2011). Park et al. (2015) conducted a study on the change of volatile organic compound emission characteristics of pine boards according to painting treatment using varnish, water-based stain, and natural oil paint. As a result of the study, it was reported that varnish emits a large amount of harmful VOCs such as toluene, xylene, and ethyl benzene from the paint itself, and that natural oil hardly emits harmful VOCs from the paint itself. The oil-based varnish in this study has the best moisture absorption suppression ability, but as in the study of Park et al. (2015), it may have problems in use, such as increased concentration of harmful VOCs in the indoor air. However, natural oil has fewer harmful VOCs emitted from the paint itself during painting, and it has an excellent moisture absorption suppression ability to compensate for defects in wood, as well as to secure healthy indoor air quality and improve the environment-friendly living environment.

\subsection{UV deterioration}

Table 4 shows the average amount of color change and the anti-color change rate of 1,2 and 3 times by

Table 4. $\mathrm{CC}^{*}, \mathrm{ACC}^{*}$ according to coating material and species

Unit: $\triangle \mathrm{E}(\mathrm{CC}), \%(\mathrm{ACC})$

\begin{tabular}{|c|c|c|c|c|c|c|c|c|c|c|c|c|c|c|c|c|c|}
\hline \multirow{2}{*}{$\begin{array}{l}\text { Coating } \\
\text { material }\end{array}$} & \multirow[t]{2}{*}{ Times } & \multicolumn{2}{|c|}{$\begin{array}{l}\text { Korean red } \\
\text { pine }\end{array}$} & \multicolumn{2}{|c|}{$\begin{array}{l}\text { Japanese } \\
\text { larch }\end{array}$} & \multicolumn{2}{|c|}{ Zelkova } & \multicolumn{2}{|c|}{ Walnut } & \multicolumn{2}{|c|}{ Merbau } & \multicolumn{2}{|c|}{ White oak } & \multicolumn{2}{|c|}{ Red oak } & \multicolumn{2}{|c|}{ Average } \\
\hline & & $\mathrm{CC}$ & $\mathrm{ACC}$ & $\mathrm{CC}$ & $\mathrm{ACC}$ & $\mathrm{CC}$ & $\mathrm{ACC}$ & $\mathrm{CC}$ & $\mathrm{ACC}$ & $\mathrm{CC}$ & $\mathrm{ACC}$ & $\mathrm{CC}$ & ACC & $\mathrm{CC}$ & ACC & $\mathrm{CC}$ & $\mathrm{ACC}$ \\
\hline Untreated & 0 & 16.3 & & 10.5 & & 1.3 & & 6.2 & & 5.4 & & 4.5 & & 10.3 & & 7.8 & \\
\hline Natural oil & $\begin{array}{c}1 \sim 3 \\
\text { Average }\end{array}$ & 10.0 & 38.6 & 11.5 & -8.6 & 2.8 & -123.3 & 1.1 & 82.7 & 7.6 & -41.8 & 5.7 & -27.7 & 7.5 & 26.6 & 6.6 & -7.6 \\
\hline $\begin{array}{c}\text { Water based } \\
\text { stain }\end{array}$ & $\begin{array}{c}1 \sim 3 \\
\text { Average }\end{array}$ & 14.9 & 8.7 & 11.0 & -4.6 & 4.9 & -289.0 & 8.0 & -28.6 & 1.6 & 70.4 & 1.3 & 70.5 & 3.1 & 70.2 & 6.4 & -14.6 \\
\hline Oil based stain & $\begin{array}{c}1 \sim 3 \\
\text { Average }\end{array}$ & 7.0 & 56.9 & 9.6 & 8.5 & 7.8 & -521.2 & 4.9 & 21.0 & 1.4 & 73.9 & 2.5 & 45.0 & 3.4 & 66.6 & 5.2 & -35.6 \\
\hline $\begin{array}{c}\text { Water based } \\
\text { varnish }\end{array}$ & $\begin{array}{c}1 \sim 3 \\
\text { Average }\end{array}$ & 13.7 & 16.2 & 10.6 & -0.4 & 5.9 & -367.7 & 8.2 & -31.6 & 3.0 & 45.1 & 2.0 & 54.8 & 2.9 & 71.4 & 6.6 & -30.3 \\
\hline $\begin{array}{l}\text { Oil based } \\
\text { varnish }\end{array}$ & $\begin{array}{c}1 \sim 3 \\
\text { Average }\end{array}$ & 6.9 & 57.7 & 8.3 & 21.2 & 2.4 & -87.8 & 2.6 & 58.0 & 7.2 & -33.9 & 4.7 & -3.8 & 3.6 & 64.5 & 5.1 & 10.8 \\
\hline \multicolumn{2}{|c|}{ Average } & 10.5 & 35.6 & 10.2 & 3.2 & 4.8 & -277.8 & 4.9 & 20.3 & 4.2 & 22.7 & 3.3 & 27.8 & 4.1 & 59.9 & 6.0 & -15.5 \\
\hline
\end{tabular}


species and paint, and Fig. 2 shows the color change and Duncan test results of unpainted wood and natural oil-painted wood according to the number of 1,2 and 3 paints by species.

The average color change of the unpainted wood was 7.8, which was 16.3 for Korean red pine, 10.5 for Japanese larch, 1.3 for zelkova, 6.2 for walnut, 5.4 for merbau, 4.5 for white oak, and 10.3 for red oak. When classifying the results based on the color judgment criteria, Korean red pine was very much graded, Japanese larch, red oak, and walnut were much graded, merbau and white oak were appreciable grade, and zelkova was found as slight grade.

The amount of color change by species type of the painted wood was Korean red pine 10.5, Japanese larch 10.2 , zelkova 4.8 , walnut 4.9 , merbau 4.2 , red oak 4.1, white oak 3.3, with an average of 10.4 for softwood and 4.2 for hardwood. When classifying the results based on the color judgment criteria, Korean red pine and Japanese larch much grade, except for the two species, other species were found to be appreciable grade. In addition, the amount of color change by paint was found to be 6.5 for water-based and 5.7 for oil-based, followed by natural oil and water-based varnish 6.6, water-based stain 6.4, oil-based stain 5.2, and oil-based varnish 5.1. When classifying the results based on the color criterion, natural oil and water-based varnish were found to be much, and oil-based varnish and oil-based stain were appreciable.

The anti-color change rate to painted wood was red oak $59.9 \%$, Korean red pine $35.6 \%$, white oak $27.8 \%$, merbau $22.7 \%$, walnut $20.3 \%$, Japanese larch $3.2 \%$, zelkova $-277.8 \%$ by species type. As a result, the average for softwoods was $19.4 \%$ and the average for hardwoods was $-29.4 \%$. By paint, oil-based varnish was $10.8 \%$, natural oil $-7.6 \%$, water-based stain $-14.6 \%$, water-based varnish $-30.3 \%$, and oil-based stain $-35.6 \%$, with an average of $-10.8 \%$ for oil-based and $-22.5 \%$ for water-based. As for the anti-color change rate of each species, other species except zelkova showed the effect of inhibiting color change during painting treatment. By paint, other paints except oil-based varnish showed low color change inhibition in wood during painting, and oil-based varnish showed the best effect of inhibiting color change. In addition, as a result of statistical analysis of Duncan test, it was confirmed that the amount of color change of the painted wood showed a significant difference with the unpainted wood due to a low color change depending on the presence or absence of painting treatment, but it was confirmed that it did not show a significant difference depending on the number of times of painting (Fig. 2). Pandey

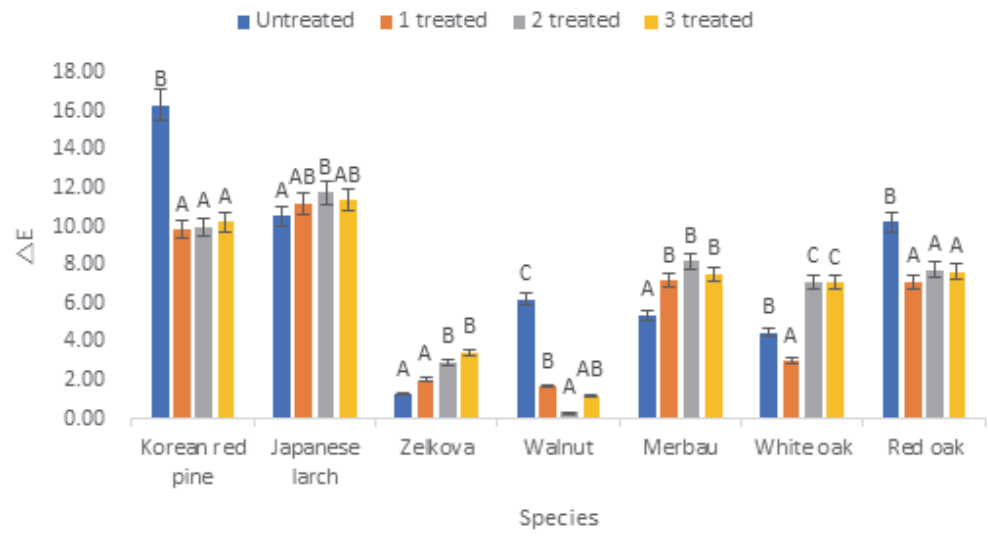

Fig. 2. Color changes of natural oil after UV irradiation aging. 
et al. (2015) reported that acetylated wood painted with polyurethane has a higher resistance to accelerated deterioration and vapor phase deterioration than untreated wood with the same coating. Lee et al. (1995) painted larch after adding UV absorbers and HALS to polyurethane varnish. As a result, it was reported that it showed the smallest change in color by reducing yellowing of the coating film and suppressing discoloration of wood, and it was reported that polyurethane varnish painting showed less color change than unpainted treatment. Dombay (1973) reported three major causes of discoloration in transparent painted wood: the yellowing and photochemical action of the paint itself, the chemical action of wood reactants and paints, and the interaction of UV, atmospheric oxygen, and moisture. Hon et al. (1984) reported that the discoloration of wood is caused by the reaction of UV with the lignin, which is the chromophore of wood, in the presence of oxygen and moisture, and that the longer the exposure time to UV, the less the aromatic component. The oil-based paints used in this study caused yellowing in the wood after painting, and it is judged that the oil varnish showed lower color changes compared to other paints due to yellowing and photochemical effects on the wood. As such, it can be seen that the color change due to UV is mainly changed by the components of the paint and lignin. It is judged that the color change caused by UV can be suppressed by chemical and physical treatments such as painting with the addition of stabilizer.

\section{CONCLUSION}

This study investigated the hygroscopicity and UV deterioration characteristics by UV to find out whether or not there is a moisture blocking effect by applying paint to major domestic and imported woods used in Korea.

Overall, the hygroscopicity of the painted wood was less absorbent than the unpainted wood, and it was found that it most effectively blocks moisture when painting 3 times than 1 or 2 times. As for chemical paints, oil-based paints showed lower hygroscopicity than water-based paints, and natural oils showed low hygroscopicity comparable to oil-based paints. In addition, hardwoods showed lower hygroscopicity than softwoods.

As for the amount of color change in wood due to UV deterioration, the color changes of the painted wood was lower than that of the unpainted wood, and there was no significant difference according to the number of coatings. By paint type, the oil-based type showed a lower amount of color change than the water-based type, and by species type, the hardwood material showed a lower amount of color change than the softwood material. Through this study, it is judged that more efficient painting performance can be achieved by selecting a paint suitable for various conditions, such as the purpose of painting, the environment of use, and the place of use.

\section{REFERENCES}

Arsyad, W.O.M., Basri, E., Hendra, D., Trisatya, D.R. 2019. Termite resistance of impregnated jabon wood (Anthocephalus Cadamba Miq.) with combined impregnant agents. Journal of the Korean Wood Science and Technology 47(4): 451-458. Chang, Y.S., Han, Y.J., Eom, C.D., Chun, S.J., Yeo, H.M. 2019. Hygroscopic property of heat treated yellow poplar (Liriodendron tulipifera) wood. Journal of the Korean Wood Science and Technology 47(6): 761-769.

Choi, K., Ji, J.Y. 2013. A study on the development plans for various surface decoration techniques of woodcraft works and wooden furniture with the utilization of environmentally friendly paint: Focusing on the juxtapositional mixture effect of 
colors and the application of wood sculpture techniques. Journal Korea Society of Visual Design Forum 38: 345-354.

Chung, B.S., Kim, S.K. 2001. Furniture Design. Seoul. Mijinsa.

Defense Acquisition Program Administration. 2008. Paint standard practical handbook. Seoul. Defense Acquisition Program Administration Standards Management Department.

Dombay, S. 1973. The influence of finish on colour changes in wood. Journal of the Oil \& Colour Chemists' Association 56(2): 77-82.

Haishi, T., Nakano, T., Kaburagi, J. 1973. Properties of important Japanese woods physical properties 4 on the moisture absorbability and swelling. Journal Article 256: 23-84.

Hoadley, R.B. 1980. Understanding wood: A craftsman's guide to wood technology. Taunton press.

Hon, D.N.-S., Chang, S.T. 1984. Surface degradation of wood by ultraviolet light. Journal of Polymer Science: Polymer Chemistry Edition 22(9): 2227-2241.

Hwang, I.S., Park, J.H., Kim, S.C. 2018. A study on the optical characteristics according to the lacquer drying conditions for the conservation of lacquerwares. Journal of the Korean Wood Science and Technology 46(5): 610-621.

Kang, C.W., Kim, N.H., Kim, B.R., Kim, Y.S., Byeon, H.S., Soe, W.T., Yoe,. H.M., Ho, S.W., Lee, W.H., Lee, H.Y. 2008. Wood Physics and Mechanical. Seoul Korea. Hyangmoonsa.

Kim, H.J., Lee, B.H. 2002. Development trends of natural coatings: Rhus lacquer, dendropanax lacquer and cashew nutshell liquid (CNSL) lacquer. Prospectives of Industrial Chemistry 5(5): 35-43. Kim, J.Y., Eom, S.H., Kim, B.R. 2018. Hygroscopic properties of major korea wood species. In: 2018 Proceedings of The Korean Society of Wood Science and Technology Spring Meeting. The Korean Society of Wood Science and Technology,
Jinju, Korea, pp. 60.

Kim, N.H., Park, H.M., Byeon, H.S., Yang, J.K., Lee, J.Y., Chong, S.H. 2006. Secondary xylem formation: Introduction to biomass science. Seoul. Life science publishing Co.

Kim, Y.J. 2010. A Study on finishing technique of woodworking furniture: Focus on oil finishing. Journal of the Korea Furniture Society 21(5): 354-366.

Kim, Y.S. 2018. Current researches on the protection of exterior wood from weathering. Journal of the Korean Wood Science and Technology 46(5): 449-470.

Korea Forest Research Institute. 1989. Wood Painting for Interior Furniture. Forestry Research Institute. Seoul. Korea.

Kwon, O.K., Kim, N.H., Kim, J.S., Seo, J.W., Chung, Y.J. 2020. Wood anatomy. Seoul. Journal of the Korean Wood Science and Technology.

Lee, D.H., Oh, H.M., Kang, C.H., Son, D.W., Kim, J.I. 2002. The evaluation of water repellent effectiveness of natural oil treated wood. Forest bioenergy 21(2): 34-42.

Lee, J.M. 2018. Distribution of moisture content in wood below fiber saturation point. Master thesis, Kyungpook University. Korea.

Lee, J.S., Kim, S.J. 2020. Evaluation of material properties of acetylated medium density fiberboard (MDF). Journal of the Korean Wood Science and Technology 48(3): 393-404.

Lee, P.W., Kang, K.T. 1995. Spectrophotometrical properties of polyurethane varnish containing UV absorber and HALS(hindered amine light stabilizer for exterior). Journal of the Korea Furniture Society. 6(1): 21-30.

Lee, S.W., Choi, K. 2011. An evaluation study on effectiveness and improvement of wood painting which used natural finishing materials: Focusing on the effect of infant and toddler's skin and 
respiratory organ. Journal of Digital Design 11(4): 101-110.

Na, W.J., Cho, S.Y., Kim, D.R., Chung, W.Y. 2015. Water resistance evaluation of the oils coating for conservation of wooden cultural heritage. Journal of Conservation Science 31(1): 13-20.

Oh, S.W., Park, H.J. 2015. Vacuum pressure treatment of water-soluble melamine resin impregnation for improvement of mechanical property, abrasion resistance and incombustibility on softwood. Journal of the Korean Wood Science and Technology 43(6): 792-797.

Pandey, K.K., Srinivas, K. 2015. Performance of polyurethane coatings on acetylated and benzoylated rubberwood. European Journal of Wood and Wood Products 3(1): 111-120.

Park, H.J., Jo, S.U. 2020. Moisture absorption and desorption properties of douglas fir, hinoki, larch, plywood, and WML board ${ }^{\mathbb{R}}$ in response to humidity variation. Journal of the Korean Wood Science and Technology 47(5): 567-578.

Park, J.H. 2010. A study on investigation and reconstruction of oil paint in Korea. Master thesis,
Chungang University. Korea.

Park, S.B., Lee, M., Lee, S.M., Kang, Y.S. 2015. VOCs emission characteristics of coating materials for wood finishing. Journal of the Korea Furniture Society 26(1): 22-30.

Park, S.H., Han, Y.J., Son, D.W. 2020. Flame retardancy of wood products by spreading concentration and impregnation time of flame retardant. Journal of the Korean Wood Science and Technology 48(4): 417-430.

Park, S.H., Han, Y.J., Son, D.W. 2021. Flame retardancy of plywood treated with various water glass concentration and additives. Journal of the Korean Wood Science and Technology 49(1): 44-56.

Park, S.Y., Hong, C.Y., Kim, S.H., Choi, J.H., Lee, H.J., Choi, I.G. 2018. Studies on Photoprotection of Walnut Veneer Exposed to UV Light. Journal of the Korean Wood Science and Technology 46(3): 221-230.

Priadi, T., Sholihah, M., Karlinasari, L. 2019. Water absorption and dimensional stability of heat-treated fast-growing hardwoods. Journal of the Korean Wood Science and Technology 47(5): 567-578. 